\title{
KOMPUTERISASI AKUNTANSI SIMPAN PINJAM DAN KREDIT BARANG PADA KOPERASI GURU DAN KARYAWAN SMA NEGERI 2 CIKARANG UTARA, BERBASIS VB.NET
}

\author{
${ }^{1}$ Dedeh Nurlaela, ${ }^{2} \mathrm{Hasmizal}$ \\ Email : dedehnurlaela29@gmail.com, hasmizal@dosen.rosma.ac.id
}

\begin{abstract}
Abstrak
Koperasi Guru dan Karyawan (KGK) SMA Negeri 2 Cikarang Utara merupakan koperasi yang bergerak di bidang simpan pinjam dan kredit barang, Pelayanan simpan pinjam dan kredit barang kepada anggotanya saat ini sudah menggunakan microsoft excel dan belum terintegrasi pada sebuah aplikasi sehingga pelayanan di koperasi tidak maksimal. Tujuan penelitian ini, untuk menyajikan informasi pendaftaran anggota koperasi, prosedur peminjaman simpan pinjam dan kredit barang, prosedur pembayaran simpan pinjam dan kredit barang serta memberikan informasi sisa pinjaman dan kredit pada anggota koperasi. Metode penelitian yang digunakan dengan metode pengumpulan data diantaranya studi kepustakaan, observasi, dan wawancara, kemudian metode perancangan yang digunakan adalah metode SDLC (System Development Life Cycle) dengan model waterfall. Hasil penelitian yang dilakukan oleh penulis di Koperasi Guru dan Karyawan (KGK) SMA Negeri 2 Cikarang Utara adalah diperlukannya sebuah aplikasi sistem informasi yang berbasis VB.Net guna mendukung kegiatan koperasi khususnya dalam pelayanan pada anggotanya. Berdasarkan hasil penelitian, dapat disimpulkan bahwa menyajikan informasi pendaftaran anggota koperasi, peminjaman simpan pinjam dan kredit barang di Koperasi Guru dan Karyawan (KGK) SMA Negeri 2 Cikarang Utara yang tadinya dilakukan dengan tulis tangan pada buku besar, namun dengan adanya aplikasi ini tidak diperlukan kembali dan terdapatnya database serta terintegrasi pada aplikasi VB.Net.
\end{abstract}

Kata kunci : Koperasi, Simpan Pinjam, Kredit Barang, VB.Net.

\begin{abstract}
Teacher and Employee Cooperative (KGK) SMA Negeri 2 North Cikarang is a cooperative engaged in the field of savings and loans and credit goods, savings and loan services and credit goods to its members are now using microsoft excel and not yet integrated in an application so that the service in the cooperative is not maximized. The purpose of this study is to present cooperative member registration information, loan saving and lending procedures, loan saving and lending procedures, and credit information to members of the cooperative. The research method used with data collection method such as literature study, observation, and interview, then design method used is SDLC (System Development Life Cycle) method with waterfall model. The results of research conducted by the author in Cooperative Teachers and Employees (KGK) SMA Negeri 2 North Cikarang is the need for an application information system based on VB.Net in order to support cooperative activities, especially in service to its members. Based on the result of the research, it can be concluded that presenting the information of member registration of cooperative, borrowing loan and credit of goods in Cooperative Teacher and Employee (KGK) SMA Negeri 2 North Cikarang which was done by hand writing at ledger, but with this application not needed again and the presence of a database and integrated in VB.Net applications.
\end{abstract}

Keywords: Cooperative, Savings and Loans, Goods Credit, VB.Net. 


\section{PENDAHULUAN}

Teknologi informasi dan komunikasi sangat berperan penting dalam memperbaiki kualitas suatu organisasi atau instansi. Penggunaannya tidak hanya sebagai proses otomatisasi terhadap akses informasi tetapi juga menciptakan akurasi, kecepatan dan kelengkapan sebuah sistem yang terintegrasi sehingga proses organisasi semakin cepat pelayanannya. Perkembangan teknologi informasi banyak dinikmati oleh berbagai sektor diantaranya ialah koperasi.

Koperasi merupakan badan usaha yang beranggotakan orang-seorang atau badan hukum Koperasi dengan melandaskan kegiatannya berdasarkan prinsip Koperasi sekaligus sebagai gerakan ekonomi rakyat yang berdasar atas asas kekeluargaan. Koperasi Guru dan Karyawan (KGK) SMA Negeri 2 Cikarang Utara merupakan koperasi yang bergerak di bidang simpan pinjam dan kredit barang. Koperasi ini melayani anggota, khususnya dalam bidang pelayanan simpan pinjam dan kredit barang. Pada bidang pelayanan pada anggotanya sekarang sudah menggunakan media komputer yang bertujuan untuk mempercepat informasi yang dibutuhkan yang mendasar dalam pencatatan yaitu debet (pemasukan), kredit (pengeluaran) ataupun hutang piutang dan sebagainya.

Pelayanan kepada anggotanya saat ini sudah menggunakan microsoft excel namun belum terdapat sistem yang terintegrasi pada koperasi simpan pinjam KGK SMA Negeri 2 Cikarang Utara, sehingga pelayanan di koperasi tersebut menjadi lambat, bahkan memakan waktu yang lama untuk mengetahui data anggota yang memiliki simpan pinjam dan kredit barang karena masih menggunakan pembukuan secara tertulis, kemudian kurang tertibnya pembukuan laporan keuangan koperasi yang mengakibatkan laporan keuangan menjadi tidak akurat dan efisien, karena harus mencari data satu persatu dengan jumlah anggota yang banyak. Maka dari itu Koperasi Guru dan Karyawan (KGK) SMA Negeri 2 Cikarang Utara membutuhkan sebuah aplikasi yang terintegrasi dan sistematis.
Aplikasi yang terintegrasi merupakan sistem informasi yang akan mempermudah koperasi didalam melakukan proses pengolahan data dengan pengambilan keputusan yang tepat bagi pihak pengelola koperasi. Karena itu, sistem informasi memegang peranan penting didalam perkembangan suatu koperasi instansi. Dengan adanya sistem informasi yang baik, maka koperasi akan memperoleh kemudahan untuk mempercepat tugas dan pekerjaan pengelola koperasi, serta meningkatkan pelayanan koperasi ini kepada anggotanya.

Berdasarkan dari uraian tersebut di atas, penulis tertarik untuk membuat rancangan sistem informasi koperasi dengan menggunakan Microsoft Visual Basic.net 2008 dengan database SQL Server 2005, dengan harapan dapat memberikan kemudahan dalam kegiatan terhadap Koperasi Guru dan Karyawan (KGK) SMA Negeri 2 Cikarang Utara dalam hal ini penulis menjadikan sebagai suatu bahasan dengan judul "Komputerisasi Akuntansi Simpan Pinjam dan Kredit Barang Pada Koperasi Guru dan Karyawan SMA Negeri 2 Cikarang Utara, Berbasis Vb.Net".

\section{METODOLOGI PENELITIAN}

Metode penelitian yang digunakan penulis untuk mengumpulkan data-data yang diperlukan sebagai bahan tugas akhir ini, diantaranya :

\section{Metode Pengumpulan Data}

Penelitian terdapat teknik pengumpulan data yang merupakan faktor penting dalam keberhasilan suatu penelitian, dimana berkaitan dengan bagaimana cara mengumpulkan data. Adapun dalam penelitian ini penulis menggunakan teknik pengumpulan data sebagai berikut :

a. Studi kepustakaan, yaitu mengumpulkan data-data sekunder yang bersumber pada buku-buku dan dokumen yang berkaitan dengan masalah yang diteliti untuk memperoleh suatu landasan teori.

b. Observasi, yaitu melakukan pengamatan secara langsung dengan objek yang diteliti, khususnya tentang simpan pinjam dan kredit barang. 
c. Wawancara, yaitu mengadakan tatap muka secara langsung dengan berbagai pihak yang terkait.

\section{Metode Perancangan}

Metode perancangan yang digunakan adalah metode SDLC (System Development Life Cycle) dengan model waterfall. Model ini memberikan pendekatan-pendekatan sistematis dan berurutan bagi pengembangan piranti lunak. Berikut gambar pengembangan sistem perangkat lunak dengan proses SDLC dengan model waterfall:

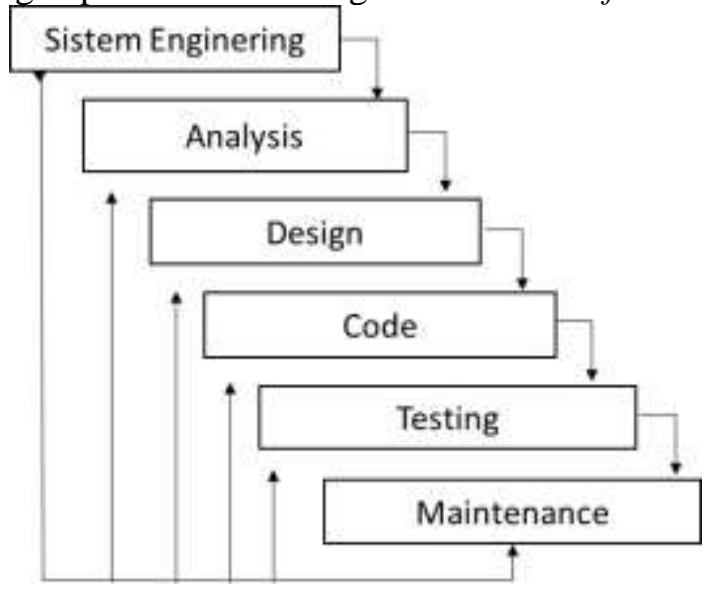

Gambar 1. Metode waterfall, (Roger S. Pressman, 2012:53)

\section{TINJAUAN PUSTAKA}

\section{Pengertian Sistem}

Menurut Sutarman (201:13), "sistem adalah kumpulan elemen yang saling berhubungan dan berinteraksi dalam satu kesatuan untuk menjalankan suatu proses pencapaian suatu tujuan utama”.

Menurut Jogiyanto (2010:2), "sistem adalah sekumpulan dari elemen-elemen yang berinteraksi untuk mencapai satu tujuan tertentu".

\section{Pengertian Informasi}

Menurut Gordon B. Davis (2012:1), "Informasi adalah data yang telah diproses ke dalam suatu bentuk yang mempunyai arti bagi si penerima dan mempunyai nilai nyata dan terasa bagi keputusan saat itu atau keputusan mendatang".
Menurut Bambang Hartono ( 2011:66), "Informasi merupakan data yang telah diolah sehingga menjadi suatu bentuk yang penting yang berguna bagi penerimanya dan mempunyai kegunaan sebagai dasar dalam pengambilan keputusan yang dapat dirasakan akibatnya secara langsung atau secara tidak langsung dimasa yang akan datang".

\section{Pengertian Sistem Informasi}

Menurut McLeod dalam Yakub (2012:8), "Sistem Informasi adalah data yang diolah menjadi bentuk lebih berguna dan lebih berarti bagi yang menerimanya".

Menurut Sutarman ( 2012:13), "sistem informasi adalah suatu sistem yang didefinisikan mengumpulkan, memproses, menyimpan, menganalisis, menyebarkan informasi untuk tujuan tertentu. Seperti sistem lainnya, sistem informasi terdiri atas input (data, instruksi) dan output (laporan)".

\section{Konsep Dasar Akuntansi}

Menurut Ismail (2010:12), “akuntansi dapat diartikan sebagai seni dalam melakukan pencatatan, penggolongan, dan pengikhtisaran, yang mana hasil akhirnya tercipta sebuah informasi seluruh aktivitas keuangan perusahaan. Tujuan akuntansi yang digambarkan dalam laporan keuangan adalah untuk memberikan informasi yang bermanfaat untuk pengambilan keputusan para pemakai.

Menurut Harrison (2012:15), "akuntansi adalah bahasa bisnis dan sistem informasi yang mengukur aktivitas, memroses data menjadi laporan serta mengkomunikasikan hasilnya bagi pengambilan keputusan".

\section{Siklus Transaksi Akuntansi}

Menurut Lilis Puspitawati dan Sri Dewi Anggadini (2014:39), "siklus transaksi akuntansi yaitu pengolahan data keuangan perusahaan diawali dari bukti transaksi yang berupa faktur, dokumen, nota, kuintansi dan bukti-bukti transaksi keuangan yang lainnya dan kemudian dicatatkan dalam pembukuan/catatan perusahaan sehingga hasil akhir dari proses pencatatan dan pengidentifikasian bukti itu akan mengasilkan informasi yaitulaporan keuangan (financial statement). Proses pengidentifikasin bukti trnasaksi dan pencatatannya dalam akuntansi dikenal dengan nama Siklus Akuntansi (Accounting Cycle), Akuntansi 
sendiri secara garis besar dapat dijelaskan sebagai proses pengolahan data transaksi keuangan dengan cara mengidentifikasikan, melakaukan pencatatan, menggolongkan, dan melaporkan hasil pemrosesan tersebut dalam suatu".

\section{Konsep Dasar Sistem Informasi Akuntansi}

Menurut Azhar Susanto (2013:52), "Sistem Informasi Akuntansi yaitu komponenkomponen yang saling berhubungan dan bekerjasama untuk mengumpulkan, memproses, menyimpan informasi untuk mendukung pengambilan keputusan koordinasi, pengendalian, dan untuk memberikan gambaran aktivitas didalam perusahaan".

\section{Pengertian Microsoft Visual Basic.Net}

Menurut Frazelli (2012:26), "Visual basic adalah salah satu bahasa pemrograman berbasis desktop yang dikeluarkan (diproduksi) oleh perusahaan perangkat lunak komputer terbesar yaitu Microsoft.

Menurut Marlon Leong (2010:3), "Visual basic adalah bahasa pemrograman yang lebih sederhana dibanding bahasa pemrograman yang lain karena visual basic membebaskan pemrogram dari penulisan perintah atau instruksi yang komplekssehingga langkah pemrograman menjadi jauh lebih sederhana".

MySQL

Menurut Diar PujiOktavian ( 2010:32), "MySQL merupakan program database server sebagai tempat penyimpanan dan pengolahan data".

Menurut Woro Widya (2010:26), "MySQL adalah salah satu software sistem manajemen database (DBMS) Structural Query Language (SQL) yang bersifat open source".

Menurut Sibero (2010:44) dalam bukunya yang berjudul Aplikasi Web Database SQL adalah suatu bahasa standar yang di gunakan oleh aplikasi untuk berkomunikasi dengan database server Struktur SQL terdiri dari dua bagian utsms yaitu DDL (Data Definion Language) adalah standar bahasa yang digunakan untuk membuat formula pengolahan data. Selain DDL dan DML, pada strktur SQL terdapat istilah Query. Query adalah suatu kumpulan perintah DDL atau DML yang diformulasikan untuk memberikan hasil data ataupun perintah yang diharapkan.

Database

Menurut Kadir dalam Mujilan (2012:23), "Database adalah sebagai suatu pengorganisasian data dengan bantuan komputer yang memungkinkan data dapat diakses dengan mudah dan cepat”.

Menurut Kustiyaningsih (2011:146), "Database adalah struktur penyimpanan data untuk menambah, mengakses dan memproses data yang disimpan dalam sebuah database komputer, diperlukan sistem manajemen database seperti Mysql Server".

Menurut Sutarman (2012:15), "Database adalah sekumpulan file yang saling berhubungan dan terorganisasi atau kumpulan record-record yang menyimpan data dan hubungan diantaranya.

\section{Pengertian Akuntansi}

Menurut Al. Haryono Jusup (2011:4), "Akuntansi dapat diartikan sebagai sistem informasi yang mengukur aktivitas bisnis, mengolah data menjadi laporan dan mengkomunikasikan hasilnya kepada para pengambil keputusan".

Menurut Anastasia dan Lilis (2011:14), Akuntansi merupakan proses mengidentifikasi, mengukur, mencatat dan mengkomunikasikan peristiwa-peristiwa ekonomi dari suatu organisasi (bisnis meupun nonbisnis) kepada pihak-pihak yang berkepentingan dengan informasi bisnis tersebut (pengguna informasi). Pada dasarnya fokus utama dari akuntansi adalah transaksi bisnis".

\section{Pengertian Koperasi}

Menurut Undang-Undang Nomor 25 Pasal 1 ayat 1 Tahun 1992 tentang Perkoperasian, "Koperasi merupakan badan usaha yang beranggotakan orang seorang atau badan hukum koperasi, dengan melandaskan kegiatannya berdasarkan prinsip koperasi sekaligus sebagai gerakan ekonomi rakyat, yang berdasarkan asas kekeluargaan".

Menurut Rudianto (2010:3), "Koperasi adalah perkumpulan orang yang secara sukarela mempersatukan diri untuk berjuang meningkatkan kesejahteraanekonomi mereka melalui pembentukan sebuah badan usaha yang dikelola secara demokratis. 
Menurut Adenk (2013:4), "koperasi adalah suatu perkumpulan yang didirikan oleh orang-orang atau badan hukum koperasi yang memiliki keterbatasan kemampuan ekonomi, dengan tujuan untuk memperjuangkan peningkatan kesejahteraan anggotanya".

\section{Koperasi Simpan Pinjam}

Menurut Burhanuddin

"Koperasi Simpan Pinjam adalah koperasi yang didirikan guna memberikan kesempatan kepada para anggotanya untuk memperoleh pinjaman atas dasar kebaikan".

Koperasi simpan pinjam berdasarkan PSAK (2007:27) adalah "Koperasi simpan pinjam adalah koperasi yang kegiatan atau jasa utamanya menyediakan jasa penyimpanan dan peminjaman untuk anggotanya."

\section{HASIL DAN PENELITIAN}

\section{Implementasi Sistem}

Implementasi sistem yang akan dilakukan oleh penulis dalam laporan tugas akhir ini khususnya sebelum menjalankan program ini, terdapat beberapa hal yang perlu diperhatikan yaitu kebutuhan sistem dan perancangan sistem, seperti ;

1. Kebutuhan Perangkat Keras yang dibutuhkan (Hardware)

Perangkat keras komputer atau yang lebih sering disebut hardware adalah perangkat fisik yang bisa disentuh, diraba dan dilihat dan fungsinya adalah untuk membantu proses komputerisasi. Adapun hardware yang dibutuhkan untuk menjalankan aplikasi Sistem Informasi Simpan Pinjam dan Kredit Barang Pada Koperasi Guru dan Karyawan SMA Negeri 2 Cikarang Utara, ini adalah sebagai berikut ;

- Jenis komputer: Intel Core 2 Duo Processor

- RAM : $4 G b$

- Harddisk : :500 Gb

- Monitor : LCD

- Keyboard dan Mouse

2. Kebutuhan Software

Spesifikasi kebutuhan perangkat lunak yang digunakan untuk menerapkan sistem/aplikasi yang akan dikembangkan, yaitu :
- Microsoft Visual Studio 2008 (Vb.Net)

- Microsoft SQL Server 2005

\section{Implementasi Sistem Koperasi}

1. Form Login

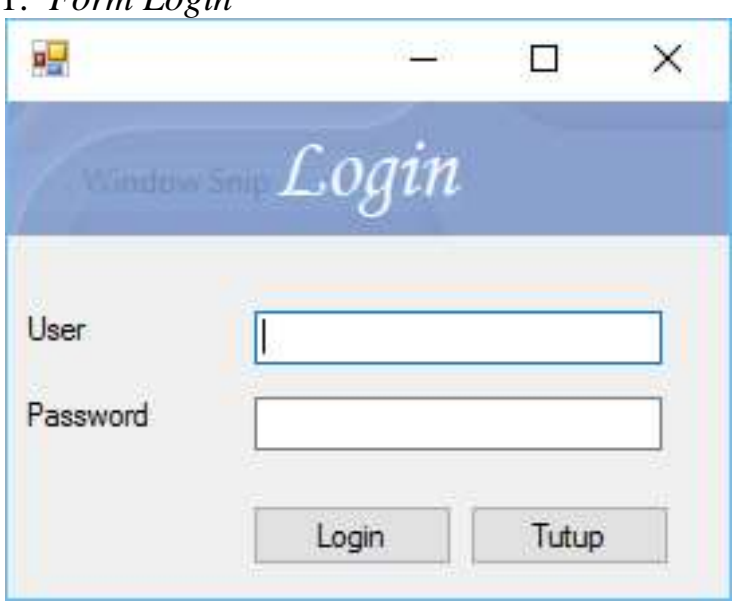

Gambar 2. Form Login

\section{Form Menu Utama}

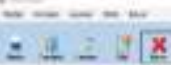

\section{12}

Gambar 3. Form Menu Utama

3. Form Data Anggota

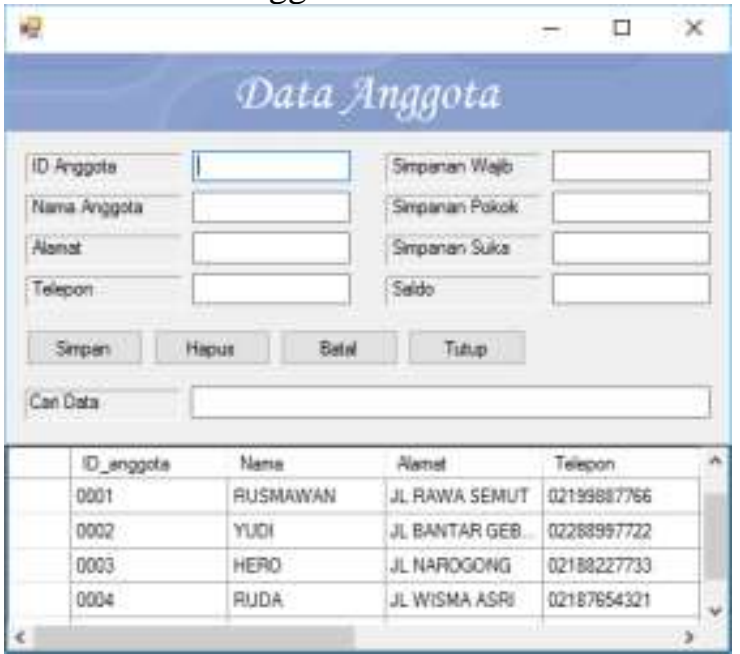

Gambar 4. Form Data Anggota 


\section{Form Data Barang}

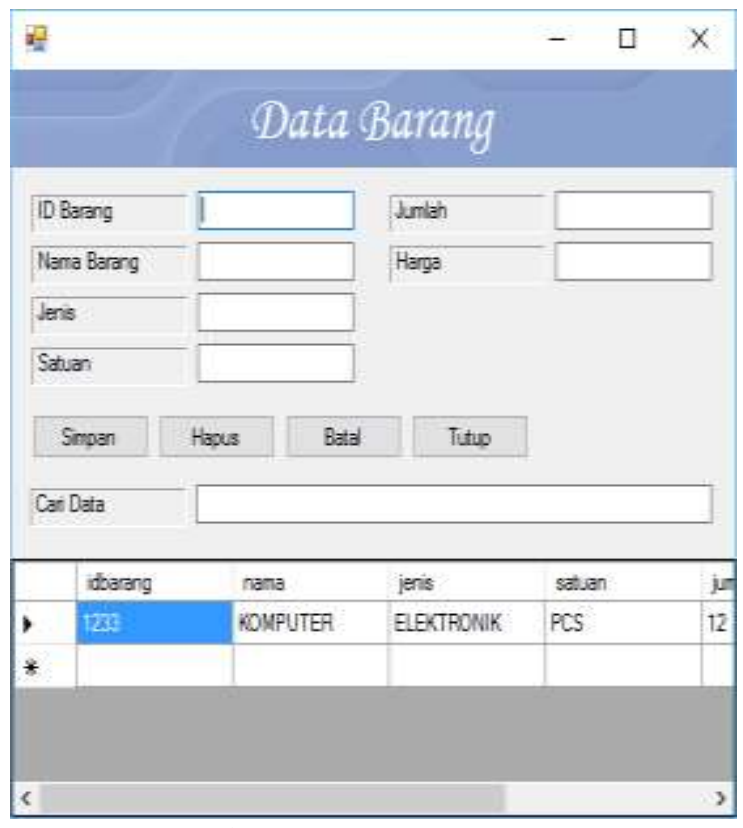

Gambar 5. Form Data Barang

\section{Form Petugas}

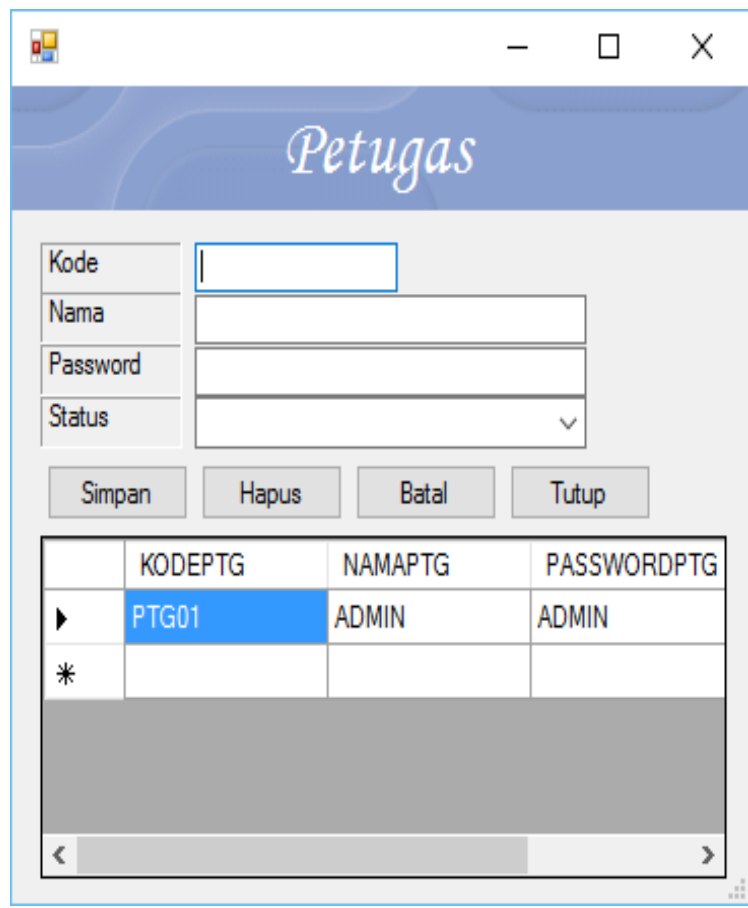

Gambar 6. Form Data Petugas

\section{Form Setoran}

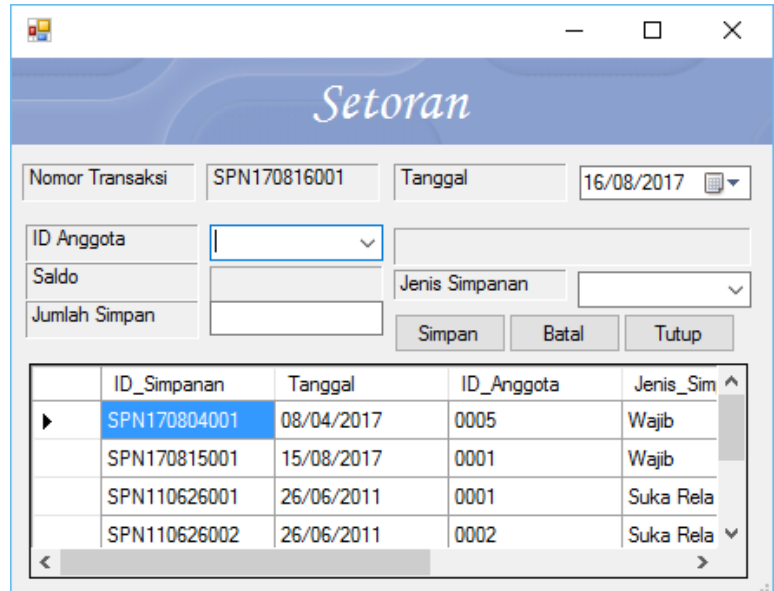

Gambar 7. Form Setoran

7. Form Pengambilan

\begin{tabular}{|l}
\hline Pengambilan \\
\hline Pag \\
\hline
\end{tabular}

Gambar 8. Form Pengambilan

8. Form Pengambilan Barang

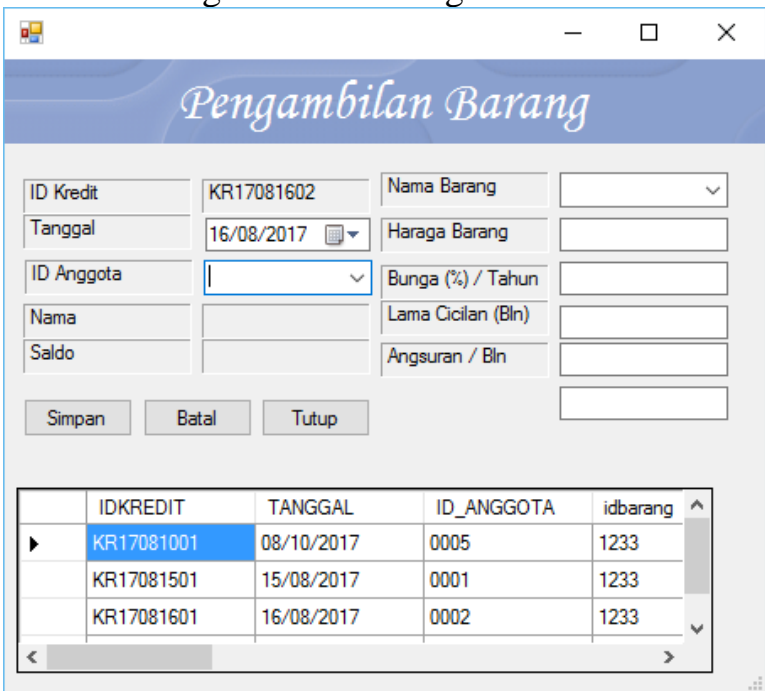

Gambar 9. Form Pengambilan Barang 
9. Form Pinjaman

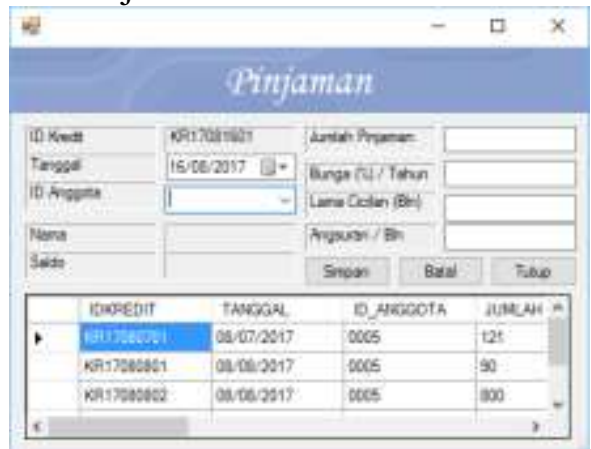

Gambar 10. Form Pinjaman

10.Form Bayar Cicilan

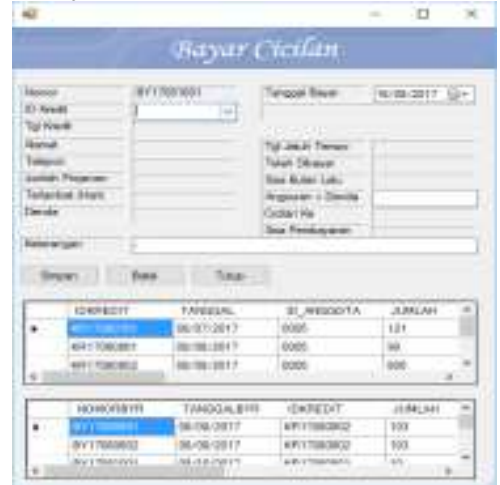

Gambar 11. Form Bayar Cicilan

11.Form Bayar Cicilan Barang

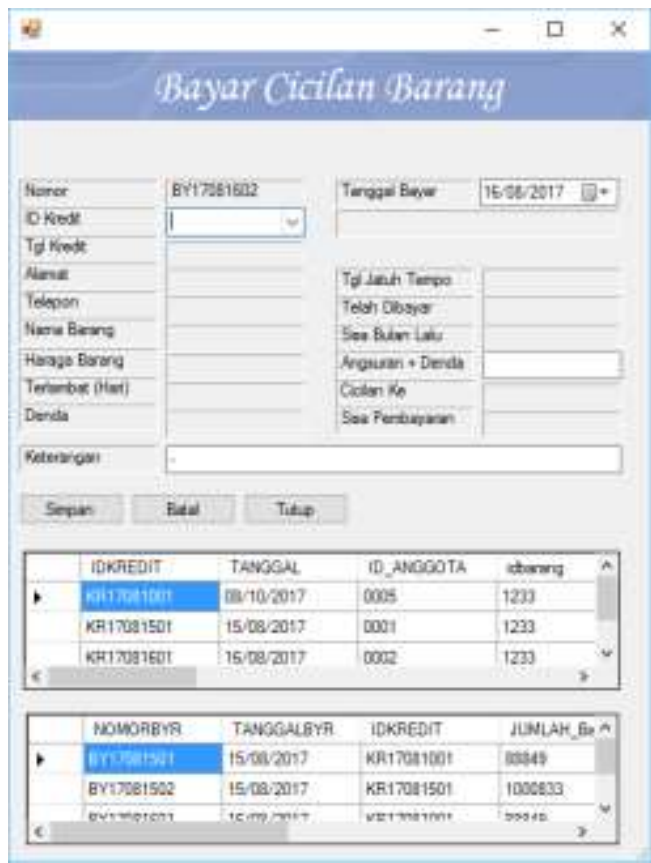

Gambar 12. Form Bayar Cicilan Barang

\section{Form Laporan}

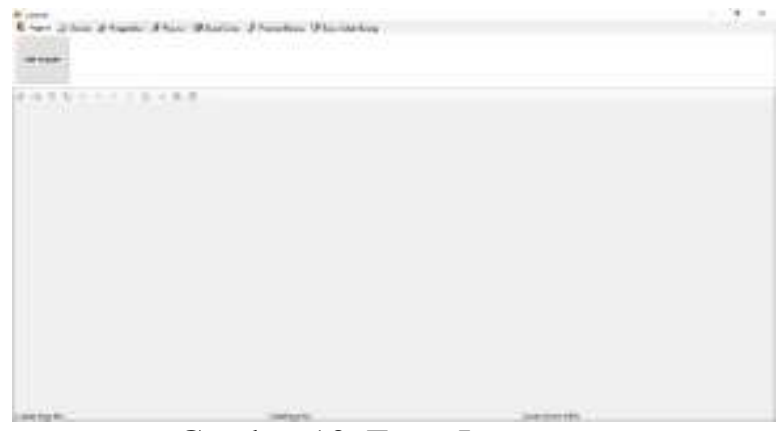

Gambar 13. Form Laporan

13.Form Hasil Laporan Data Anggota

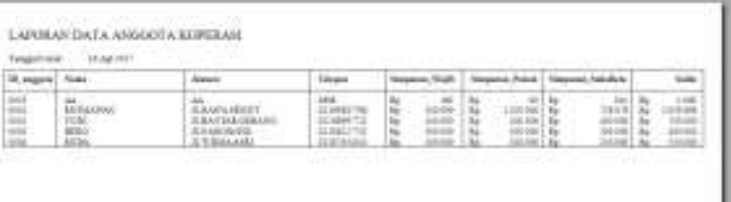

Gambar 14. Form Hasil Laporan Data Anggota

14.Form Hasil Laporan Pembayaran

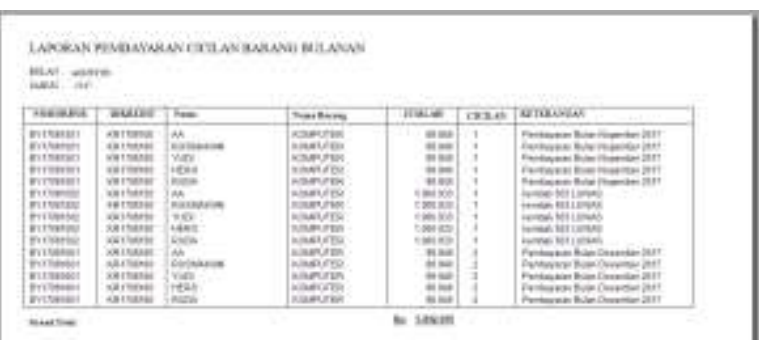

Gambar 15. Form Hasil Laporan Pembayaran

15.Form Hasil Laporan Pembayaran Pinjaman Barang

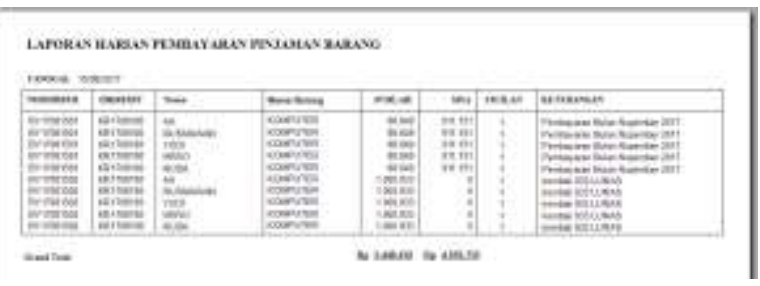

Gambar 16. Form Hasil Laporan Pembayaran Pinjaman Barang 
16.Form Hasil Laporan Pembayaran Cicilan Bulanan

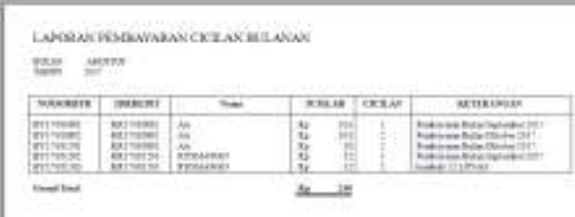

Gambar 17. Form Hasil Laporan Pembayaran Cicilan Bulanan

17.Form Hasil Laporan Harian Pembayaran Pinjaman

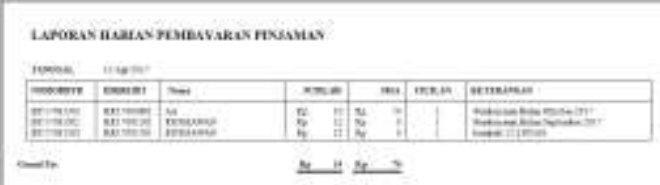

Gambar 18. Hasil Laporan Harian Pembayaran Pinjaman

18.Form Hasil Laporan Pengambilan Bulanan

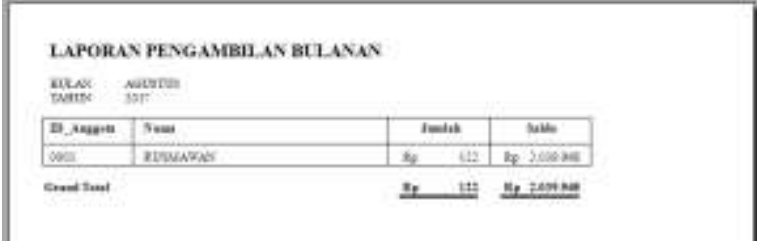

Gambar 19. Form Hasil Laporan Pengambilan Bulanan

19.Form Hasil Laporan Pengambilan Harian

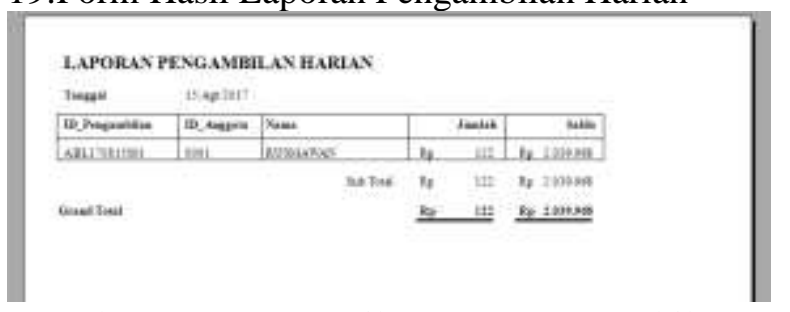

Gambar 20. Form Hasil Laporan Pengambilan Harian

20.Form Hasil Laporan Bulanan Pinjaman Barang

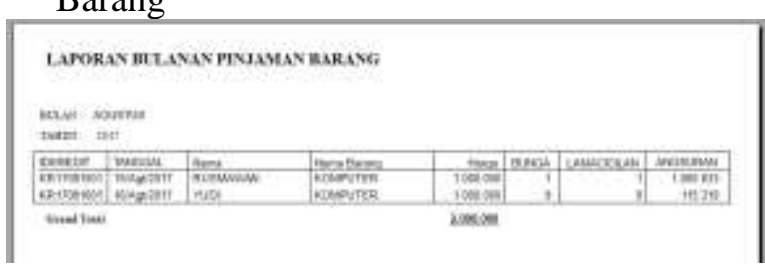

Gambar 21. Form Hasil Laporan Bulanan Pinjaman Barang
21.Form Hasil Laporan Harian Pinjaman Barang

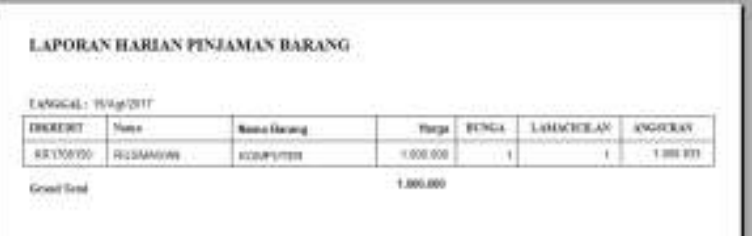

Gambar 22. Form Hasil Laporan Harian Pinjaman Barang

22.Form Hasil Laporan Bulanan Pinjaman Berjangka

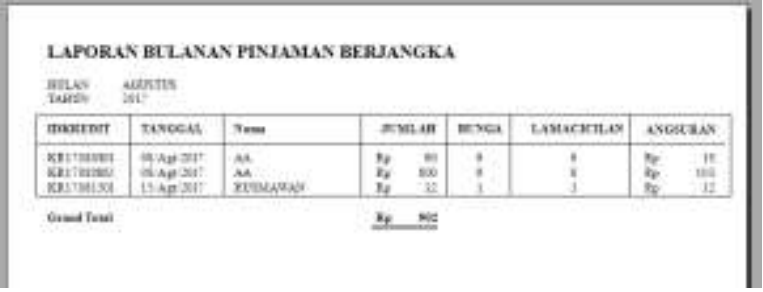

Gambar 23. Form Hasil Laporan Bulanan Pinjaman Berjangka

23.Form Hasil Laporan Harian Pinjaman Berjangka

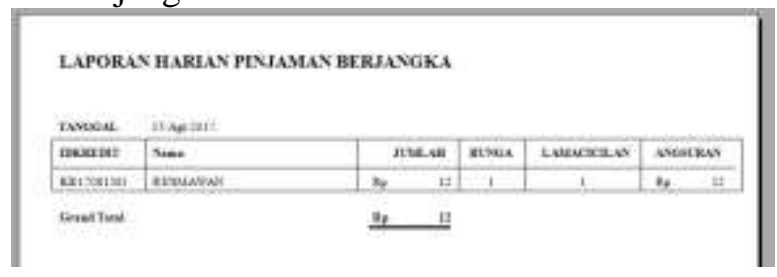

Gambar 24. Form Hasil Laporan Harian Pinjaman Berjangka

24.Form Hasil Laporan Setoran Bulanan

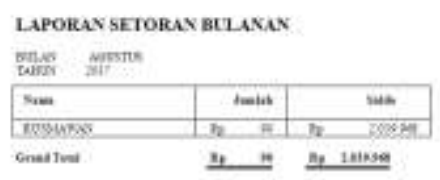

Gambar 25. Form Hasil Laporan Setoran Bulanan

25.Form Hasil Laporan Setoran Harian

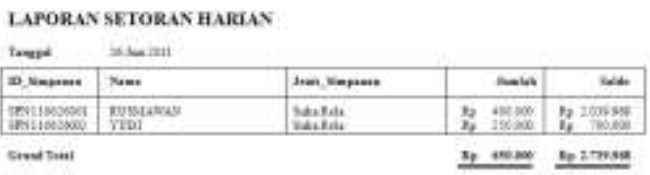

Gambar 26. Form Hasil Laporan Setoran Harian 


\section{KESIMPULAN DAN SARAN}

\section{Kesimpulan}

Hasil akhir dari laporan tugas akhir dengan mengambil judul Sistem Informasi Simpan Pinjam dan Kredit Barang Pada Koperasi Guru dan Karyawan SMA Negeri 2 Cikarang Utara, Berbasis Vb.Net, di dapatkan kesimpulan, diantaranya ;

a. Rancangan, pembuatan dan penyajian informasi simpan pinjam yang dibuat pada Koperasi Guru dan Karyawan SMA Negeri 2 Cikarang Utara diharapkan mampu untuk menanggulangi dan meminimalisir permasalahan yang terjadi di Koperasi tersebut khususnya pada informasi simpan pinjam yang dibutuhkan oleh Koperasi dalam hal ini Ketua Koperasi ataupun anggota koperasi.

b. Rancangan, pembuatan dan penyajian informasi kredit barang pada Koperasi Guru dan Karyawan SMA Negeri 2 Cikarang Utara diharapkan mampu untuk menanggulangi dan meminimalisir permasalahan yang terjadi di Koperasi tersebut khususnya pada informasi kredit barang yang dibutuhkan oleh Koperasi dalam hal ini Ketua Koperasi ataupun anggota koperasi.

c. Rancangan, pembuatan dan pengendalian simpan pinjam dan kredit barang pada Koperasi Guru dan Karyawan SMA Negeri 2 Cikarang Utara, diharapkan dapat menanggulangi pengendalian simpan pinjam dan kredit barang yang terjadi di Koperasi tersebut khususnya pada informasi simpan pinjam dan kredit barang yang dibutuhkan oleh Koperasi dalam hal ini Ketua Koperasi ataupun anggota koperasi.

d. Penyajian informasi mengenai simpan pinjam anggota dan kredit barang anggota Koperasi Guru dan Karyawan SMA Negeri 2 Cikarang Utara, dapat membantu pengurus Koperasi dalam memperoleh informasi simpan pinjam dan kredit barang secara cepat oleh para anggota koperasi.

\section{Saran}

Hasil pengamatan dan analisa selama melakukan pengumpulan data di Koperasi Guru dan Karyawan SMA Negeri 2 Cikarang Utara adalah sebagai berikut :

a. Sebelum menerapkan aplikasi ini perlu dilakukan uji coba (trial error) dan selama masa uji coba sistem yang lama tetap dipakai.

b. Jika hasil coba (trial error) menunjukan hasil yang positif maka dibutuhkan pelatihan bagi pengurus/karyawan Koperasi yang terlibat dalam penggunaan aplikasi ini.

c. Sistem komputerisasi perlu diterapkan pada Koperasi Guru dan Karyawan SMA Negeri 2 Cikarang Utara, walaupun pada saat ini sistem belum efektif untuk dapat diterapkan secera meyeluruh karena akan dapat merubah keadaan dari sistem yang ada.

\section{DAFTAR PUSTAKA}

Abdul Kadir. 2014. Pengenalan Sistem Informasi Edisi Revisi. Yogyakarta. Andi.

Al-Bahra Bin Ladjamudin. 2013. Analisis dan Desain Sistem Informasi. Yogyakarta. Graha Ilmu.

Azhar Susanto. 2013. Sistem Informasi Akuntansi. Bandung: Lingga Jaya.

Burhanuddin. 2010. Aspek Hukum Lembaga Keuangan Syariah. Yogyakarta. Graha Ilmu.

Dewi Oktarita Sari, Kusrini. 2011. Perancangan Sistem Informasi Keuangan Pada Koperasi Simpan Pinjam Dasa Wisma Gunungkrambil Rt 01 Gunungkidul. JURNAL ISSN: 1411-3201. Vol. 12 Nomor 3.

Gordon B. Davis, 2012. Kerangka Dasar Sistem Informasi Manajemen, PT Pustaka Binamas Pressindo, Jakarta.

Hadi dan Fami. 2010. Pengantar Manajemen Perkreditan. Bandung. Alfabeta.

Hall, James A, 2013. Sistem Informasi Akuntansi, Edisi Ketiga. Jakarta. Salemba Empat.

Harrison, Walter. T. Jr. et.al. 2012. Akuntansi Keuangan: International Financial Reporting Standars. Penerjemah Gina Gania. Jakarta: Erlangga. 
Hartono, Bambang. 2011. Sistem Informasi Manajemen Berbasis Komputer. Jakarta. Rineka Cipta.

Ismail. 2010. Akuntansi Bank. Jakarta. Penerbit Kencana.

Jogiyanto 2010 Pendekatan Terstruktur Teori dan Praktek Aplikasi Bisnis. Analisa dan Desain Sistem Informasi. Yogyakarta. Andi Offset.

Jogiyanto, Hartono. 2011. Analisis dan Desain Sistem Informasi, Edisi III. Yogyakarta. ANDI.

Kadir, Abdul. 2012. Pemograman Database Dengan Delphi 7 Menggunakan Access dan ADO. Yogyakarta. Andi.

Leong. Marlon. 2010. Pengantar Sistem Informasi.Yogyakarta. Graha Ilmu.

Oktavian. Diar Puji. 2010. Menjadi Programmer Jempolan Menggunakan PHP. Yogyakarta: Penerbit MediaKom

Romney, Marshall B., dan Steinbart, paul J. 2012. Accounting Information Systems. Global Edition. Twelfth Edition. England: Pearson Education Limited.

Rudianto. 2010. Akuntansi Koperasi. Erlangga Jakarta.

Sibero, C Ivan. 2010. Membuat Game 2D Menggunakan Game Maker. Yogyakarta. MediaKom.

Sudarwanto. Adenk. 2013. Akuntansi koperasi . Graha Ilmu. Yogyakarta.

Supriyatna, Adi. 2014. Sistem Informasi Pinjaman Dana Dan Pembelian Barang Secara Kredit Berbasis Web. Jurnal Paradigma vol XVI Nomor.2

Sutabri. Tata. 2012. Sistem Informasi Manajemen, Penerbit Andi. Yogyakarta.

Sutanta, Edhy. 2011. Basis Data dalam Tinjauan Konseptual. Yogyakarta. Andi.

Sutarman. 2012. Pengantar Teknologi Informasi. Jakarta: Bumi Aksara.

Widya.woro. 2010. Aplikasi pemograman web dinamis dengan phpdam MySql. Yogyakarta. GavaMedias.

Yakub. 2012. Pengantar Sistem Informasi. Yogyakarta. Graha Ilmu.

Zaliluddin, Dadan. 2016. Sistem Informasi Simpan Pinjam Koperasi BMT Baburahman dengan Menggunakan
Visual Basic. Infotech Journal ISSN : 2460-1861. Vol 2, Nomor 1.

Undang-Undang Nomor 25 Tahun 1992 tentang Perkoperasian.

Undang-Undang Republik Indonesia Nomor 10 Tahun 1998 Tentang Perubahan Atas Undang-Undang Nomor 7 Tahun 1992 Tentang Perbankan.

Pernyataan Standar Akuntansi Keuangan (PSAK) Nomor 27 tahun 2007 tentang Akuntansi Perkoperasian) 